\title{
Analysis of pedagogical and cultural situations from the vantage po- int of discourse analysis
}

Antonio José Murillo-Murgueítio

Universidad Distrital Francisco José de Caldas

anjomu@col1.telecom.com.co

\begin{abstract}
This paper encompasses analyses of pedagogical and cultural situations from the perspective of some of the authors studied in our discourse analysis class. Cultural authenticity and cultural stereotypes are dealt with stemming from real issues and mirroring them through the lens of Kramsch's (1998) insights. McCarthy (1994) is referred to when a curricular principle, the familiar to unfamiliar principle is considered as a pedagogical approach in ESL teaching.
\end{abstract}

\section{RESUMEN}

Este documento contempla el análisis de situaciones pedagógicas y culturales desde la perspectiva de algunos de los autores estudiados en nuestra clase de Análisis de Discurso. Se trata el tema de la autenticidad cultural y los estereotipos Culturales partiendo de eventos reales y observándolos a través de la lente reflexiva de Kramsch (1998). Se hace referencia a McCarthy (1994) cuando un principio curricular, el principio de lo familiar a lo no-familiar es considerado como un enfoque pedasógico en la enseñanza de ESL. 


\section{INTRODUCTION}

Although each case in this paper is treated separately, the intention is to surface the feasibility of the reading material in relation to teaching issues within our pedagogical performance, as brought up by the professor along the course syllabus. Discourse Analysis, with all its many possibilities sharpens our educational and cultural senses. We well know that nothing in teaching "comes out of the blue" to say it through an idiomatic expression and meaning that everything has a reason, an intention, an action and a reaction.

\section{RATIONALE}

This paper is justified inasmuch as it is a practical application of the different readings, authors, and perspectives developed during class hours. Theory without application becomes futile; therefore, these reflections are validated as an effort to connect with classroom situations or cultural issues.

\section{THEORETICAL FRAMEWORK}

INITITIAL QUESTION: What happens in the EFL classroom in relation to cultural authenticity?

"Language learners, keen on slipping into someone else's shoes by learning their language, attach great importance to the cultural authenticity of French bread, German train schedules and the cultural appropriateness of Japanese salutations or Chinese greeting ceremonies. Their desire to learn the language of others is often coupled with a desire to behave and think like them (the underline is added), in order to ultimately be recognized and validated like them." (Kramsch,1998:80).

I will begin by paraphrasing an anecdote related to an English language teacher at a reknown English Institute in Colombia who, in order to supposedly motivate his students, told them: "OK Let's speak American".

As a witness to the scene, the statement appeared ridiculous and shocking to me then, but it implies more than just a matter of personal appreciation.

Was the teacher pretending to make his students like "them", Americans? Kramsch states (p. 80):"Much of the discussion surrounding the native speaker 
has been focused around two concepts: authenticity and appropriateness. Later on (p.81) she clarifies:"However, two factors are putting the notion of authenticity and appropriateness into question. First, the diversity of authenticities within one national society, depending on such contextual variables as age, social status, gender, ethnicity, what is authentic in one context might be inauthentic in another. Second, the undesirability of imposing on learners a concept of authenticity that might devalue their own authentic selves as learners" (underlined added).

The teacher in the previous anecdote, a native-like speaker of English, was not only proclaiming his authenticity of the language but also imposing it on his learners. His short sentence: "OK, Let's speak American" was sending waves against their won authenticity as classroom participants of an EFL class and most of all as members of a national society.

\section{REFLECTION}

Taking into account what Kramsch names "the diversity of authenticities" (1998: 81), what could the EFL teacher do to avoid imposing a one-sided authenticity in the EFL classroom? To begin with, revising the book one works with, might be a good step in considering "diversity of authenticities". That is why I began, first browsing and later scanning such a pedagogical tool. My source of scrutiny was "New Interchange 2" (J.C. Richards, J.Hull and S.Proctor 1992). I first looked at its syllabus, where I found a topical listing. Initially, I thought this might shrivel my students' authenticity in my class setting, a private university in Bogotá. Once inside the book, what might have become a shudder of disgust turned into a satisfying assessment in relation to this concept, diversity of autheticities (Kramsch, 1998: 81). Units in "New Interchange 2"(J.C. Richards, 1992) are presented culturally and multiethnically varied; accents in the recording were not the "standard" English type, but with South American, Asian, or African-American variants. My students were not going to be culturally alienated or offered a stereotyped English language from the perspective of a diverse contemporary world where English is not any more a one-nation language but an international medium of communication.

Speaking of stereotypes, not only they tend to surface in the microcosm of a classroom or a book, but at a larger extent in society as a whole, to which I would like to allude in the next section. 


\section{CULTURAL STEREOTYPES}

"It has to be noted that societies impose racial and ethnic categories only on certain groups". (Kramsch, 1998: 68.)

Colombia is one of those countries where, looking at the cédula (I.D.), you can instantly corroborate such statement. In my book "Soy Afrocolombiano" I contest that imposition. "Tome usted dos personas, una de raza india o mestiza cuyo color de piel puede ser ébano y tome el color de la piel de un persona afro cualquiera, que probablemente tenga el mismo tono de piel que la primera persona. Una va a ser llamada "trigueña" la otra "morena".

Tome el tono de piel de una persona blanca, tipo sajón - aquí mal llamados " monos" (ique fauna!); ahora tome el tono de piel de una persona blanca no sajona, del llamado tipo mediterráneo. La primera va a ser llamada "trigueña clara" y probablemente la segunda será clasificada "trigueña". Going back to Kramsch (1998: 66):"For example, in 1993 the South African government changed the racial classification of 690 people: two - thirds of these, who had been Coloreds, became Whites, 72 who had been Blacks became Coloreds, and 11 Whites were redistributed among other racial groups"!

The reader may find a contrasting relationship between two different cultures, the South African and the Colombian culture with one similar official attitude towards racially classifying people.

When you go to the corresponding office that provides you with your cédula (I.D.), racial classification may be considered imposed on you, in this case "Moreno" or any other, if you will. In Murillo (1997: 10) it is read: "El término Afrocolombiano tiene sentido porque define una identidad nacional que viene de allá (África) y viene de acá" (Colombia), a line to explain why the term "moreno" is more a societal racial classification imposition rather than a culturally accurate determination.

As much as we have to be aware of cultural stereotypes, as teachers in the EFL classroom we need to be alert to culturally contextualized teaching. That is my next topic of interest hereunder.

TEACHING TEXTS: CURRICULAR- DOSERES PRINCIPLES (McCarthy, M \& Carter, R., 1994) In the chapter "Literature, Culture and Language as Discourse" (McCarthy, M. E Carter, R. 1994) five principles are offered in 
relation to text-based language teaching. I chose the "Familiar to unfamiliar principle" as a frame of reference to some of the latest classroom developments with my students.

Related to the principle, the authors (1994: 167): "In terms of language learning it states that learners are more likely to be motivated to learn a second or foreign language if the texts and contexts designed into a course are culturally familiar".

At the Modern Languages Curricular Project at a public university's undergraduate program in Bogotá, I am currently developing a course called "Communication in English VIII." The syllabus emphasizes all kinds of communicative activities including sketches, which are short, and light, informal skits. I certainly have a book of sketches, "Sketches from the English Teaching Theatre" (1995) produced by the BBC. Their topic: situations around life in England. Initially, I thought of giving copies of the different sketches to the students as I have done with other groups in previous years. Based on the "Familiar to unfamiliar principle", I changed my approach. This time the suggestion to the students was to produce their conversational sketches based on familiar situations surrounding their lives. And they did so. Not only did they display their social sensibility to their own culture, but they also felt more at ease replicating their own environment through language. The aforementioned principle is applicable to other areas of EFL teaching and I did likewise without knowing the principle but preventing cultural alienation in the classroom, while teaching Elements of American Literature in High School some years ago. When folk tales was the subject of study through a book that only included North American folktales, students were encouraged to find out about Colombian and/or Latin American folktales. Motivation towards the topic increased, they delved into their own culture finding out about national Folktales and related stories throughout other Latin American countries. What was initially a handicap was turned into a learning opportunity.

\section{CONCLUSIONS}

This paper has permeated classroom, pedagogical, and cultural situations in the light of at least two authors. This at the same time shows how feasible it is to apply the theoretical framework of the course in specific teaching or 
cultural settings. I have been pleased to sense that Discourse Analysis, as a subject matter, is like the Open Seas that expand more and more right in front of one's eyes, offering almost limitless possibilities.

\section{REFERENCES}

KRAMSCH, C. Language and Culture (1998). London. Oxford University Press.

RICHARDS, J.C. HULL, J. PROCTOR, S. New Interchange 2 (1997) London. Cambridge University Press.

McCARTHY, M. \& CARTER, R. (1994). Language and Discourse Perspectives for Language Teaching. London and New York. Longman MURILLO, A.J. Soy AfroColombiano. (1997) Bogotá. Editorial Bolivar 


\section{Graduate Students Theses in Progress}

- Academic Writing for prospective English teachers at Universidad de la Amazonía. Victor Raúl Rodríguez A.

- Reading engagement in an academic context: Students' self perception of their development as readers. Eduardo Di Ridolfo

- Exploring EFL students' writing through hypertext design. Maria Eugenia López

- EFL undergraduate students' understanding of autonomy and the reflection in their learning process. Aleida Ariza Ariza

- Student teachers' construction of pedagogical knowledge through reflection. John Jairo Viafara

- Promoting a teachers' study group as a way to reflect upon their reading beliefs and practices. Martha Sofia Hernández

- English teachers' beliefs about communicative competence and the relation to their teaching practices. Moravia Elizabeth Gonzalez

- Second graders' literacy development through the use of computers. Javier Hernández Huertas

- Collaborative work: a chance for English and Science teachers to share their understandings about their teaching practices. Marcela Alfonso

- Students' perceptions of writing through dialogue journal exchange with their teacher. Hasper José Ree

- Creating literature circles: a way to share literate voices beyond the classroom bounds. Claudia Marcela Chapetón

- How does a lawyer interpret English penal texts. Francisco Ayala 


\section{THESES TITLES}

- Writing short stories through literary language interpretation Alonso Hernández Martin

- An Inquiry based program towards the construction of the peace culture at school. Angel Mario Díaz

- Grammar learning through games and communicative activities. Alvaro Henry Corredor R.

- Power relations in the E.F.L. classroom. Bertha Ramos Holguín

- Students' perceptions about their role as learners in a rural school setting

Lisbeth Mora Acosta

- Afrocolombian students and identity: a case study Antonio José Murillo Murgueíto

- Exploring students' cultural awareness through students' reflections upon culture based on EFL materials

Mireya Esther Castañeda

- Empowering learners through a pedagogy that promotes critical literacy Carmen Rojas

- Gender differences among teachers' collaboration for curricular innovations.

Norma Constanza Durán

- Exploring critical thinking in $9^{\text {th }}$ graders through the use of authentic materials.

Ivan Aguirre

- Preschool preservice teachers' beliefs of hypertext in EFL teaching.

Catalina Molina

- Team reflective work in teachers' development process 


\title{
ALCALDÍA MAYOR DE BOGOTÁ, D.C. \\ SCHOOL OF SCIENCES AND EDUCATION \\ MASTERS PROGRAM IN APPLIED \\ LINGUISTICS TO THE TEACHING OF ENGLISH \\ EIGHTH ROUND TABLE \\ ON APPLIED LINGUISTICS ISSUES
}

27th- 28th November 2003

\begin{abstract}
ARCHIVO GENERAL DE LA NACIÓN
Carrera 6 No. 6-91 BOGOTÁ, D.C.
\end{abstract}

The Masters Program in Applied Linguistics to TEFL is pleased to present its Eighth Round Table on Applied Linguistics issues.

The event will focus on research and current issues in Applied Linguistics and language teaching and will address the implications of bilingualism in Bogotá and Cundinamarca

The main purpose of the Round Table is to present research in progress to the academic community at Universidad Distrital.

\section{THURSDAY, NOVEMBER 27TH}

\section{8:00-8:30 Registration. \\ 8:30-9:00 Opening}

9:00-10:30 Maestros, niñ@syjóvenes escritores de hiperhistorias: una experiencia en lengua materna y lengua extranjera. Amparo Clavijo, Ph.D and Antonio Quintana, M.A U. Distrital

Coffee break

11:00-12:00

The Design of Instruments for Qualitative Research (Second Semester Students)

$12: 00-2: 30$

Lunch

3:00-5:00

Research projects in progress by fourth semester students.

3:00-4:00 Room A: Afro Colombian students and identity: a case study.

Antonio José Murillo.

Empowering Learners through a pedagogy that promotes 


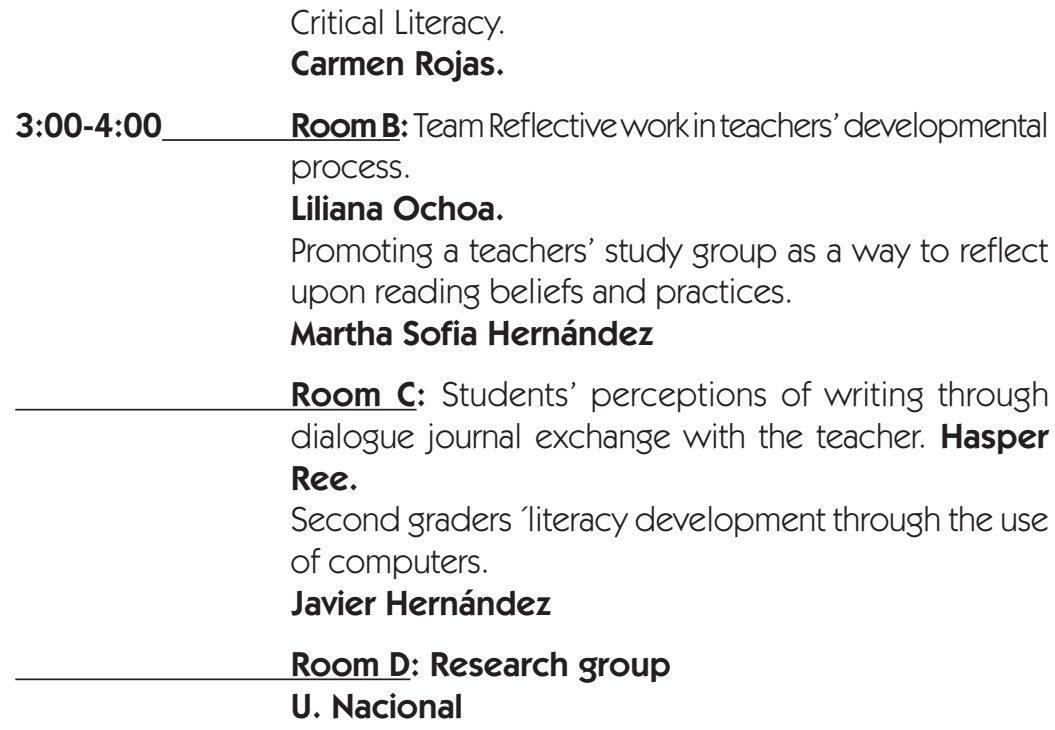

Room C: Students' perceptions of writing through dialogue journal exchange with the teacher. Hasper Ree.

Second graders 'literacy development through the use of computers.

Javier Hernández

Room D: Research group

\section{U. Nacional}

4:00-5:00 Room A: Creating literature circles: a way to share literate voices beyond the classroom bounds.

Marcela Chapetón

Writing short stories through literary language interpretation

Alonso Hernández

Room B: Students' construction of pedagogical knowledge through reflection.

John Jairo Viafara

English Teachers' beliefs on Communicative Competence and their relationship with their teaching practice.

\section{Moravia Elizabeth González}

Room C: EFL undergraduate students' understanding of autonomy and their reflection in their learning process.

\section{Aleida Ariza Ariza}

Academic Writing for prospective English Teachers at Universidad de la Amazonía.

Víctor Raúl Rodríguez.

Room D: Toward an improvement of my chore as educational English teacher: the educational software, a means to solve some methodological difficulties of English in pre-service teachers. Research Group U. 
Distrital

FRIDAY, NOVEMBER $28^{\text {TH }}$

8:30-10:00 Linguistic, Social, and Cultural aspects of becoming

bilingual.

Professors: Claudia Torres and Alvaro Quintero U.

Distrital

Lionel Antonio Tovar. U. del Valle

10:00-10:30 Break

10:30-12:00 Panel

Dra. Claudia Ordóñez. U de los Andes.

Prof. Melba L. Cárdenas. U. Nacional

Jan Van de Putte. British Council

Dra. Clelia Pineda Baez. U. Externado de Colombia.

Representante de FECODE

$12: 00-2: 30$

\section{Lunch Break}

3:00-5:00 Research Projects in progress.

3:00-4:00 Room A: Reading Engagement in an academic context: Students' self perception of their development as readers.

Eduardo Di Ridolfo

How does a lawyer interpret English penal texts.

Francisco Ayala

\section{Room B:}

Exploring students' cultural awareness through their reflections upon culture based on EFL materials.

Mireya Castañeda

Students' perceptions about their role as learners in a 
rural school setting

\section{Lisbeth Mora Acosta}

Room C: An inquiry based program towards the construction of peace culture

Ángel Mario Díaz

Collaborative work: a chance for English and Science

teachers to share their understandings about their

teaching practices

Marcela Alfonso

Room D: Research group

\section{U. de Antioquia}

4:00-5:00 Room A: Power relations in the E.F.L. classroom Bertha Ramos Holguín

Gender differences among teachers' collaboration for curricular innovations

\section{Norma Constanza Durán}

Room B: Exploring EFL students' writing through hypertext design.

\section{María Eugenia López}

Preschool preservice teachers' beliefs of hypertext in EFL teaching.

\section{Catalina Molina.}

\section{Room C:}

Grammar learning through games and communicative activities

\section{Àlvaro Herny Corredor}

Exploring critical thinking in $9^{\text {th }}$ graders through the use of authentic materials.

\section{Ivan Aguirre}

Room D: Research group

\section{U. del Tolima}

Primary School Teachers from Cundinamarca will display the outcomes of their curricular activities in English 


\section{Guidelines for contributors}

The Colombian Applied Linguistics Journal, CALJ, is an annual publication of the College of Sciences and Education, Master Program in Applied Linguistics of Universidad Distrital in Bogotá, Colombia for professionals interested in research and teaching issues in the field of Applied Linguistics for the Teaching of English. This journal is mainly concerned with informing the academic community about current completed and ongoing research relevant to teaching and learning English as a foreign language.

This journal attempts to disseminate ideas related to classroom issues and to provide a forum for discussion on teaching. A further concern is to promote the exchange of information among members of the profession.

The editors of CALJ are the professors from the M.A. Program at Universidad Distrital. Teacher educators and researchers from 13 Universities collaborate in the evaluation of articles. Authors should send their manuscripts to:

CALJ, Editors

Maestría en Lingüística Aplicada

Universidad Distrital

Calle 34 No. 13-15 Of. 405

Bogotá, Colombia

Manuscripts relevant to research and classroom issues in English teaching, are welcome and should be submitted to the editor in duplicate and with a masnetic copy. An abstract should be prepared for each article (limited to 120 words). Each table and figure should be submitted on a separate pase and should be titled. The majority of CALJ readers research and teach English and disciplines related to foreign language teaching in Colombia and abroad. The length of your article will depend on the topic, and maybe on the section for which you are submitting it. Manuscripts should be typed and double spaced throughout not exceeding 15 letter size pases or 6,000 words. 
The APA manual ought to be followed for style. Bibliographic citations in the text must include the author's last name, and the date of publication and may include pase references. Complete bibliographic information for each citation must be included in the list of references.

To assure impartial review each manuscript should be accompanied by a cover sheet with the title; author's name, position, address, fax number and E-mail address; and a short (less than 50 words) biodata statement. Identifying information should not appear elsewhere in the manuscript in order to insure anonymity for the board of reviewers.

Publication. It will be assumed that your article has not been published in another publication and that it has not been considered by another publication. Upon publication, authors will receive four complimentary copies of the issue in which their article appears. Manuscripts are not returned to authors. Authors should retain a personal copy. If your article is accepted, be prepared to revise it if necessary, in order to shorten it or to clarify something, for example. Generally, if major changes are necessary, either the article will be returned to you for amending or the edited version will be sent to you for approval.

Copyright. Any copyrighted articles appearing in CALJ are reprinted with the permission of the copyright owners. These articles may not be reproduced in whole or in part, without the written permission of the copyright owners, except as otherwise authorized by applicable copyright law. Acknowledgements and copyright notices, when necessary, appear with the articles. If you wish to use the article again in a publication written or edited by you, you may do so provided that its original publication in CALJ is acknowledged.

For further information you may contact:

CALJ Editors

Fax: (1) 3406651

E-Mail: maestria@udistrital.edu.co

Phone: (1) 3406651 


\title{
MAESTRIA EN LINGÜÍSTICA APLICADA A LA ENSEÑANZA DEL INGLES TITULOS DE NUEVAS PUBLICACIONES
}

\author{
APRENDIENDO A ENSEÑAR INGLÉS A NIÑOS. \\ Amparo Clavijo Olarte Ph.D y Esperanza Torres Mesa M.A. (Editoras) \\ Programa de Capacitación de Docentes de Primaria \\ Gobernación de Cundinamarca - U. Distrital \\ Julio, 2003
}

\section{PRESENTACIÓN}

La propuesta de formación tiene por objeto realizar una reflexión académica sobre los procesos de aprendizaje, las metodologías de enseñanza y el desarrollo de competencias lingüísticas de Ingles como Lengua extranjera con 700 docentes de Primaria de 14 Municipios de Cundinamarca. Se espera alcanzar los siguientes objetivos específicos en la formación de docentes.

\section{OBJETIVOS}

1. Familiarizar a los docentes de Primaria con algunas teorías sobre adquisición de Ingles como lengua extranjera.

2. Analizar los factores que intervienen en el aprendizaje de una segunda lengua.

3. Examinar la contribución de la lengua materna al aprendizaje de la lengua extranjera y viceversa.

4. Analizar el proceso de desarrollo de los procesos de lectura y escritura en segunda lengua en los niños.

5. Examinar y analizar diversas posibilidades de construcción de syllabus para la enseñanza de segunda lengua en la primaria.

6. Examinar los principios del plan de clase.

7. Familiarizarse con un amplio repertorio de actividades apropiadas para la enseñanza de la segunda lengua en primaria.

La propuesta esta organizada en cinco módulos, así: 
Modulo 1 Adquisición de segunda lengua.

Modulo 2 Relación entre la adquisición de la lengua materna y el aprendizaje de una segunda lengua.

Modulo 3 Educación Lingüística

Modulo 4 Planeación de la enseñanza de la segunda lengua: actividades y materiales.

Modulo 5 Desarrollo profesional.

El video sobre Teaching English in The Primary Classroom de Susan Halliwell servirá de ayuda visual para los maestros en formación de Primaria.

MAESTROS, NIÑOS Y JÓVENES ESCRITORES DE HIPERHISTORIAS: UNA EXPERIENCIA PEDAGÓGICA EN LENGUA MATERNA Y LENGUA EXTRANJERA. DICIEMBRE 2003.

Amparo Clavijo Olarte Ph.D

Antonio Quintana Ramírez M.A.

Taller de Publicaciones de la Universidad Distrital

Esta publicación tiene como propósito compartir una experiencia de formación de docentes de Inglés en la cual se utilizó el hipertexto como estrategia para fomentar la escritura creativa en primera y segunda lengua. El estudio exploratorio se desarrolló como parte del curso "aplicaciones de hipermedia en primera y segunda lengua" con estudiantes de segundo año de la Maestría en Lingüística Aplicada a la Enseñanza del Ingles. A su vez los docentes-estudiantes implementaron la estrategia pedagógica con nin@s, jóvenes y adultos de niveles de educación básica, media y universitaria. De esta implementación se hizo el registro y posterior descripción de los eventos más relevantes y de los cuales se da cuenta en este libro. 


\section{MEMBER SHIP}

Colombian Applied Linguistics Journal is published once a year. New and renewal suscriptions, and requests for sample copies, should be sent to: CALJ Suscriptions, Calle 34 No.13-15 piso 4. Bogotá, Colombia. Telefax: 3406651

\section{Member Ship Rates}

Institutional: $\quad \$ 30.000 .00$ annual

\section{Personal*: $\quad$ \$10.000.00 annual.}

${ }^{*}$ Personal rates apply only when copies are sent to a private address and payment is made to Universidad Distrital. Prices include postage by airmail.

\section{Payment Information}

Payment is required with all orders and suscriptions to Banco de Occidente account number 230-81459-2 from Universidad Distrital.

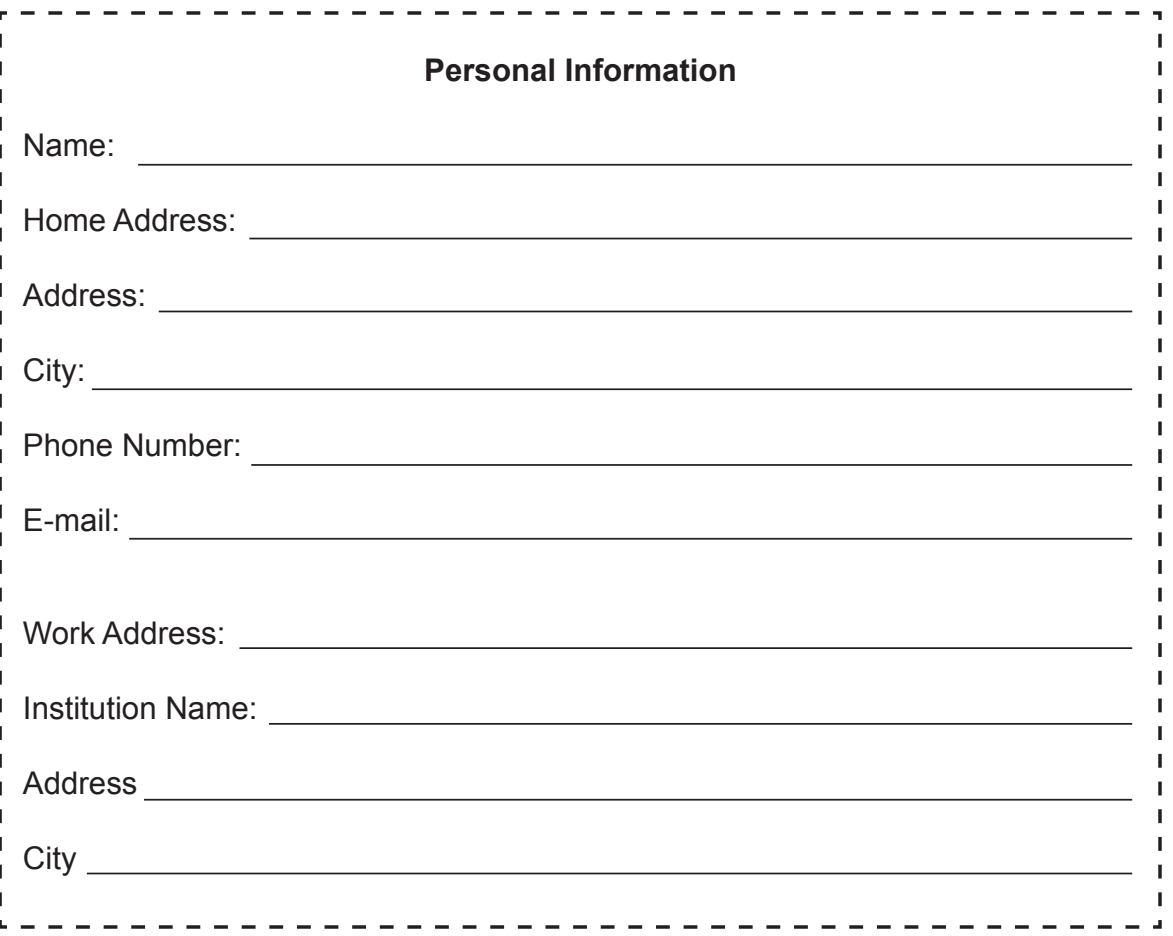

